\title{
Role of Melatonin, Galanin, and RFamide Neuropeptides QRFP26 and QRFP43 in the Neuroendocrine Control of Pancreatic $\beta$-Cell Function
}

\author{
lacopo Gesmundo, Tania Villanova, Dana Banfi, Giacomo Gamba and Riccarda Granata* \\ Division of Endocrinology, Diabetes and Metabolism, Department of Medical Sciences, University of Turin, Turin, Italy
}

Glucose homeostasis is finely regulated by a number of hormones and peptides released mainly from the brain, gastrointestinal tract, and muscle, regulating pancreatic secretion through cellular receptors and their signal transduction cascades. The endocrine function of the pancreas is controlled by islets within the exocrine pancreatic tissue that release hormones like insulin, glucagon, somatostatin, pancreatic polypeptide, and

\section{OPEN ACCESS}

Edited by:

Jacques Epelbaum,

Institut national de la santé et de la recherche médicale

(INSERM), France

Reviewed by:

Carlos Dieguez,

Universidade de Santiago

de Compostela, Spain

Nicolas Chartrel,

INSERM, France

*Correspondence:

Riccarda Granata

riccarda.granata@unito.it

Specialty section:

This article was submitted to Neuroendocrine Science,

a section of the journal

Frontiers in Endocrinology

Received: 20 March 2017 Accepted: 06 June 2017

Published: 03 July 2017

Citation:

Gesmundo I, Villanova T, Banfi D, Gamba G and Granata R (2017) Role of Melatonin, Galanin, and RFamide Neuropeptides QRFP26 and QRFP43

in the Neuroendocrine Control of

Pancreatic $\beta$-Cell Function.

Front. Endocrinol. 8:143.

doi: 10.3389/fendo.2017.00143 ghrelin. Moreover, both exocrine and endocrine pancreatic functions are regulated by a variety of hormonal and neural mechanisms, such as ghrelin, glucagon-like peptide, glucose-dependent insulinotropic polypeptide, or the inhibitory peptide somatostatin. In this review, we describe the role of neurohormones that have been less characterized compared to others, on the regulation of insulin secretion. In particular, we will focus on melatonin, galanin, and RFamide neuropeptides QRFP26 and QRFP43, which display either insulinotropic or insulinostatic effects. In fact, in addition to other hormones, amino acids, cytokines, and a variety of proteins, brain-derived hormones are now considered as key regulators of glucose homeostasis, representing potential therapeutic targets for the treatment of diabetes and obesity.

Keywords: neurohormones, melatonin, galanin, QRF26, QRFP43, pancreatic $\beta$-cells

\section{INTRODUCTION}

Type 1 and type 2 diabetes (T2D) are characterized by a reduced insulin secretion from the pancreas, due to shortage of $\beta$-cells and decreased $\beta$-cell function. Because both types of diabetes eventually lead to $\beta$-cell loss, a major goal in research is to identify strategies to preserve $\beta$-cell mass and increase $\beta$-cell function $(1,2)$. Pancreatic exocrine and endocrine secretion is partly controlled by neuronal projections from the vagus nerve, as well as many hormones produced in peripheral tissues, including the gastrointestinal tract. These comprise the gastric peptide ghrelin, the intestinal peptides glucagon-like peptide 1 (GLP-1) and glucose-dependent insulinotropic polypeptide, somatostatin, produced by pancreatic $\delta$-cells, or the adipose tissue-derived peptide leptin. Insulin release by $\beta$-cells is also influenced by non-hormonal signals, such as small proteins, amino acids, lipids, and cytokines. Moreover, recent studies have demonstrated that different neuropeptides are implicated in the regulation of glucose homeostasis and $\beta$-cell function, providing a physiological link between the brain and the endocrine pancreas $(3,4)$.

In the present review, we describe the role of neurohormones whose effects on insulin secretion and glucose homeostasis have been less well characterized compared to others. These include neuropeptides mainly displaying inhibitory functions on insulin secretion, such as the chronobiotic 
hormone melatonin, produced in the pineal gland, and galanin, released by the central and peripheral nervous systems and the gastrointestinal tract. Furthermore, we illustrate the effects of the hypothalamic RFamide peptides QRF26 and QRFP43, which, in addition to regulating feeding behavior, display both insulinostatic and insulinotropic actions and also promote pancreatic $\beta$-cell survival. Overall, because of their different ability to regulate $\beta$-cell function and glucose homeostasis, these hormones may be considered as potential therapeutic agents in diabetes and metabolic diseases.

\section{Melatonin}

Melatonin is a hormone predominantly produced by the pineal gland of the mammalian brain. It is synthesized and secreted in a circadian manner at night and functions as chronobiotic agent, regulating the seasonal and circadian rhythms, such as the sleep-wake cycle. Therefore, it is a "Zeitgeber," entraining circadian rhythm and indicating the time of day to various different organs and tissues in the body (5). In addition to the pineal gland, melatonin is produced by neuroendocrine cells in the retina and peripheral tissues, such as gastrointestinal tract, pancreas, and immune cells. In fact, because of its widespread production, melatonin acts in both endocrine and paracrine/ autocrine manner. Furthermore, its effects have been shown in the cardiovascular and immune system, and on the regulation of metabolic functions (6-8).

At the cellular level, melatonin signals through two inhibitory G-protein (Gi)-coupled receptors, MT1 and MT2, whose binding results in inhibition of cAMP production. These receptors are widely distributed in the brain as well as in peripheral tissues, including the pancreas $(9,10)$. Furthermore, melatonin binding sites in cell nuclei of rat liver hepatocytes have been demonstrated (11) and identified as retinoid-related orphan receptor, mediating the genomic effects of the hormone $(12,13)$. Melatonin also interacts with cytosolic proteins, including calmodulin and calreticulin, implicated in the regulation of the cytoskeleton and the control of nuclear receptors $(14,15)$.

Interestingly, a variant of the human melatonin receptor $1 \mathrm{~b}$ gene (MTRB1) has been associated with high plasma glucose levels, reduction of insulin response to glucose, and increased risk of T2D (16-18). However, the role of melatonin on insulin secretion has not been clearly elucidated, as both inhibitory and stimulatory actions have been reported, probably because of the pleiotropism at the level of the receptor and second messengers $(10,19)$. Interestingly, most studies suggest that melatonin inhibits insulin secretion from pancreatic $\beta$-cells (20-22), while there are reports showing lack of effect (23). In fact, in INS-1 pancreatic $\beta$-cells, expressing MT1 receptors, acute treatment with melatonin inhibited GLP-1-induced insulin secretion. However, prolonged pretreatment with melatonin, enhanced insulin secretion in the presence of either the cAMP activator forskolin or GLP-1. Similar findings were observed in isolated rat islets (24). In another study, Peschke et al. demonstrated that melatonin inhibits cAMP and insulin secretion in INS-1 $\beta$-cells stimulated with forskolin, in a $G \alpha_{i}$-dependent manner. Melatonin also inhibited insulin release in INS-1 cells treated with the inositol trisphosphate stimulator carbachol; however, in pertussis toxin (PTX)-incubated cells, the hormone increased carbachol-induced insulin release. These results suggested that in $\beta$-cells, MT1 receptor activates different signaling pathways displaying opposite effects on insulin secretion (25). Interestingly, downregulation of MT1 receptor expression in INS-1 $\beta$-cells reduced the insulinostatic effect of melatonin, indicating that, at least in rodent $\beta$-cells, the effects of the hormone are mainly mediated by this isoform of the receptor (26). Recently, rat islets and INS-1 cells were found to express MT2 (27), which is also involved in the inhibitory effect of the hormone on insulin secretion $(27,28)$. Of note, in isolated human pancreatic islets expressing both MT1 and MT2, melatonin promotes insulin secretion, in contrast with the effects in rodent $\beta$-cells and islets, possibly through an indirect action involving stimulation of glucagon secretion following its binding to MT1 receptors (29). In addition, melatonin has been shown to promote the secretion of glucagon in pancreatic $\alpha$ TC1. $9 \alpha$-cells, expressing MT1 and MT2, treated with different concentrations of glucose (30). Furthermore, long-term administration of melatonin resulted in elevation of plasma glucagon concentrations in Wistar rats (WR), whereas in type 2 diabetic Goto-Kakizaki rats glucagon levels were decreased compared to untreated animals (30). Interestingly, mRNA expression for glucagon receptor, which was slightly reduced in the liver of untreated GK rats compared to WR, was upregulated by melatonin in GK rats and decreased in WR. Furthermore, MT1 and MT2 mRNA was elevated in the liver of MT1 or/and MT2 knockout (KO) mice compared to wild-type animals, suggesting that melatonin influences pancreatic glucagon secretion and displays metabolic effects in the liver.

With regard to melatonin and glucose homeostasis, it has been demonstrated that high levels of melatonin, due to blindness (31) or to exogenous administration of melatonin, result in an increase in blood glucose levels (32); moreover, glucose levels are reduced and insulin levels increased after pinealectomy $(33,34)$. However, most studies suggest that the pineal gland has an inhibitory effect on pancreatic $\beta$-cell function, as melatonin reduces insulin levels and glucose tolerance in animals and humans (35-38). Furthermore, elevation of insulin has been shown to inhibit the synthesis of melatonin from the pineal gland (39). Collectively, these findings suggest an antagonism between insulin and melatonin functions. This is further sustained by the fact that in man, insulin levels are elevated during the day and low at night, whereas the opposite occurs for melatonin (40); interestingly, diabetic patients show an abnormal circadian rhythm of melatonin (5). In addition, melatonin has been shown to promote the expression and release of $\mathrm{GH}$ and prolactin in female primates through MT1 (41), and the secretion of prolactin in humans (42-44), whereas ACTH secretion was found to be inhibited in the mouse pituitary corticotrope tumor cell line AtT20 (45). Hence, some of the actions of melatonin on glucose metabolism may be mediated by its effects on secretion of pituitary hormones.

A recent study has demonstrated that the risk variant rs10830963 of MTNR1B is an expression quantitative trait locus (eQTL), conferring increased expression of MTNR1B mRNA in human islets, which likely results in a reduction in insulin 
secretion and increased risk of T2D (22). Furthermore, melatonin was found to inhibit cAMP levels and insulin secretion in INS-1 832/13 $\beta$-cells, and these effects were further enhanced in $\beta$-cells overexpressing MTNR1B (22). Of note, melatonin is a prescription drug for improving sleep and for jet lag (8); therefore, it should be carefully administered in individuals with sleep disturbances, particularly in obese patients and carriers of the MNTR1B risk allele. However, administration of melatonin has been shown to improve sleep quality independently of rs10830963 genotype, despite the negative effect on insulin secretion (22). Moreover, the reduction of insulin release at night, mediated by the high levels of melatonin, when the metabolic demands are low because of reduced food intake, may be a protective physiological mechanism to prevent nocturnal hypoglycemia (22).

Interestingly, mice with a disruption of the receptor have been shown to secrete more insulin, despite no change in glucose levels, suggesting reduced insulin sensitivity but unchanged insulin tolerance (22). In addition, melatonin treatment in a human recall-by-genotype study was found to reduce insulin secretion in all subjects and to increase glucose levels; moreover, insulin reduction was even enhanced in individuals with the risk variant (22). Collectively, these findings suggest that increased melatonin signaling in islets impairs $\beta$-cell function, resulting in hyperglycemia and increased risk of T2D.

\section{Galanin}

Galanin, a 29- to 30-amino acid neuropeptide initially discovered in porcine intestine (46), is expressed in the central and peripheral nervous systems and intestinal neuroendocrine system of many mammalian species (47-51). Galanin co-localizes and is coexpressed in neurons with a number of neurotransmitters and displays strong inhibitory effect on synaptic transmission (52-55). Because of its broad expression, galanin regulates many neuronal functions, such as memory and learning, neuropathic pain, neuroprotection, and neuroendocrine activity, representing a therapeutic potential for diseases such as Alzheimer's disease, epilepsy, and diabetes (51, 56-58). Three distinct G-proteincoupled receptors GalR1, GalR2, and GalR3 are involved in the effects of the neuropeptide. GalR1 and GalR3 are coupled to the inhibitory G-protein Gi, whereas GalR2 associates with either $\mathrm{Gi}$ or $\mathrm{Gq} / 11$, thus displaying both inhibitory or stimulatory responses $(51,59)$.

Galanin-positive nerve fibers have been shown in the pancreas of different species, including rat, mouse $(60,61)$, and humans (62-64). Furthermore, a number of studies have indicated that galanin displays strong inhibitory effects on insulin secretion. In fact, galanin administration was found to reduce insulin levels in many species (65-67). In addition, a whole-genome profile study has demonstrated that the expression levels of a number of hippocampal genes, including galanin, and from the prefrontal cortex, such as GalR2, were dysregulated in type 2 diabetic rats, further suggesting the importance of the galanin system and the complexity of insulin signaling in modulating brain functions (68). Interestingly, infusion of galanin into animals through the pancreatic artery, at a concentration similar to that released from stimulated pancreatic nerve termini, resulted in inhibition of insulin secretion (69). However, conflicting results have been reported in humans, as galanin either suppresses insulin levels $(70)$ or has no effect $(71,72)$. Moreover, galanin levels were inversely correlated with plasma insulin levels in postmenopausal women, whereas in controls there was a positive correlation (73).

Galanin and galanin analogs have been shown to reduce glucose-induced insulin secretion in isolated rat and pig islets $(66,74-76)$. The inhibitory action on insulin secretion in rat and mouse islets was found to involve a $\mathrm{G}_{02}$ protein, through the regulation of both $\mathrm{K}_{\mathrm{ATP}}$ and $\mathrm{Ca}^{2+}$ channels $(60,77)$. In line with these inhibitory effects, galanin infusion increased the levels of blood glucose in dogs but not in humans $(69,78)$. Furthermore, glucagon levels are upregulated by galanin, suggesting a role for glucagon in mediating the effects of galanin in glucose increase $(49,69)$.

Of note, transgenic mice overexpressing galanin showed visceral adiposity, increased body weight, increased serum cholesterol and triglycerides, hyperinsulinemia, and impaired glucose tolerance, indicating that elevated circulating galanin levels contribute to the development of metabolic syndrome (79). The obese phenotype was observed in the absence of increased food intake, suggesting defects in energy expenditure, since these mice had reduced oxygen consumption, as well as carbon dioxide and heat production (79). Surprisingly, mice with a loss-of-function mutation in the galanin gene [galanin KO mice] showed impaired inhibition of insulin secretion after activation of autonomic nerve, suggesting that galanin may act on sympathetic nerves to inhibit insulin secretion (80). Furthermore, insulin secretion was found reduced in galanin $\mathrm{KO}$ mice in response to glucose and arginine, compared to wild-type mice, and $\beta$-cells showed reduced sensitivity to glucose (80). Collectively, these findings suggest that in addition to regulating energy expenditure, galanin may be involved in the regulation of normal $\beta$-cell function. Conversely, galanin infusion has no effect on glucose tolerance in humans $(71,81,82)$ and does not influence the postprandial rise of plasma glucose levels (70).

Reduced levels of pancreatic galanin were found in obese, hyperinsulinemic mice (83), and galanin-expressing cells were found to be strongly reduced in islets of diabetic rats (61). Interestingly, in rat and bovine pancreatic islets, galanin-like immunoreactivity co-localized with that of insulin, suggesting that galanin may influence insulin secretion in an autocrine/paracrine manner $(61,84)$. Furthermore, administration of a centrally active galanin analog with high affinity for GalR1 has been recently shown to reduce insulin secretion and promote hyperglycemia, providing a further understanding on the role of GalR1 in vivo (85).

However, a beneficial effect for galanin in animal models of diabetes has been also reported (86), therefore, additional studies are required to shed light on the role of galanin in human metabolic disorders and diabetes. Importantly, intranasally administered galanin-like peptide (GALP), whose aminoacid sequence 9-21 is identical to that of galanin 1-13, reduces body weight, food intake, water intake, and locomotor activity in leptin-deficient $o b / o b$ mice and in diet-induced obese (DIO) mice (87). The decrease in body weight was found to be stronger in hyperglycemic 
compared to mormoglycemic mice, suggesting that intranasally administered GALP displays its best effect in obese mice with higher glucose levels. Interestingly, in DIO mice, the decrease in body weight after intranasal treatment with GALP was observed in spite of a reduction in locomotor activity, suggesting that GALP restrains energy intake and promotes energy expenditure (87). Other studies have demonstrated that intracerebroventricular GALP reduces food intake and stimulates energy expenditure; however, these effects did not persist over time, suggesting that the mice become insensitive to repeated treatment with GALP (88, 89). Conversely, repeated intranasal administration of GALP continued to decrease food intake and locomotor activity compared with repeated intracerebroventricular injection, suggesting that sensitivity to GALP is maintained and intranasal administration is the best way for GALP to exert its effects against obesity (87).

\section{RFamide Neuropeptide QRF26 and QRF43}

The neuropeptide QRFP26 and its N-extended form QRFP43 are members of the RFamide peptide family, discovered in 2003 by three different groups (90-92). The gene encoding the QRFP26/ QRFP43 precursor is widely distributed among vertebrates, including humans, mice, rats (90-92), and other species (93-95), indicating that these neuropeptides have been highly conserved during evolution (96).

QRFP26 and QRFP43 are the cognate ligands of the former orphan receptor GPR103, also called SP9155 or AQ27, and now renamed QRFPR $(90,97)$. QRFPR is a G-protein-coupled receptor, with a $52 \%$ amino acid identity with neuropeptide FF receptor 2 (NPFF2), another receptor for mammalian RFamide peptides. However, whereas QRFP26 also displays low moderate affinity for NPFF2, QRFP43 only binds to QRFPR, which, in turn, is not recognized by other mammalian RFamide peptides (98). Two isoforms have been described for QRFPR (QRFPR1 and QRFPR2) in rodents, sharing high homology with the unique form of human QRFPR, and QRFP26/QRFP43 bind with similar affinity to both forms of the receptor in rodents $(99,100)$.

The genes for QRFP26/QRFP43 precursor and QRFPR are mainly located in the hypothalamic nuclei, as well as in other brain areas involved in the control of feeding behavior $(90,101)$. Accordingly, intracerebroventricular (i.c.v.) injection of both QRFP26 and QRFP43 in mice has been shown to promote food intake and to increase body weight and fat mass (90, 97, 100, 102, 103). In addition to the central distribution, QRFP26/ QRFP43 and QRFPR are expressed in peripheral organs, including adipose tissue and macrophages (104-106), eye, trachea, mammary gland, and testis, endocrine glands, including the pituitary, thyroid, and parathyroid glands, coronary artery, gastrointestinal tract, bladder, and prostate $(91,92,100,107)$. Thus, because of the broad distribution of QRFPR, QRFP26/QRFP43 have been shown to regulate a variety of physiological functions, including adipogenesis, lipolysis and inflammation (104-106), blood pressure (100), bone formation (108), and hypothalamopituitary-gonadal activity $(109,110)$.

Although initially not found in mouse and rat pancreas (91, 92), expression of QRFP26/QRFP43 and QRFPR mRNA and protein was later found in human endocrine pancreas and isolated pancreatic islets $(107,111)$, rat INS-1E $\beta$-cells (111), and mouse insulinoma MIN6 cells (107). Moreover, in human islets, QRFPR co-localized with insulin, suggesting autocrine/ paracrine action of locally produced QRFP26/QRFP43 and direct binding of the peptides with its receptor in pancreatic $\beta$-cells (111).

Interestingly, QRFPR displays sequence similarity with NPY and galanin receptors (112), and like NPY and galanin, QRFP26/ QRFP43 have been shown to regulate insulin secretion. In fact, QRFP26 was found to reduce glucose-, arginine-, and exendin4 -induced insulin secretion in rat perfused pancreas, showing no effect on glucagon secretion. Since the insulinostatic action of QRFP26 was inhibited by PTX upon treatment with exendin-4, it was suggested the involvement of a pertussis-sensitive $\mathrm{G} \alpha$ inhibitory $\left(G \alpha_{i}\right)$ protein negatively coupled to the adenylyl cyclase pathway (113). However, the authors of this study were unable to identify the receptor implicated in these effects, likely because previous reports failed to demonstrate QRFPR expression in the pancreas $(91,92)$.

In accordance with the findings of Egido et al. (113) QRFP26 was later found to inhibit glucose- and exendin-4-induced insulin secretion in INS-1E $\beta$-cells and human pancreatic islets, through mechanisms mediated by $G \alpha_{i}$ and reduction of intracellular cAMP levels (111). Of note, knocking down QRFPR in these cells did not affect the insulinostatic action of QRFP26, suggesting the involvement of a different receptor. By contrast, QRFP43 potentiated insulin secretion in $\beta$-cells and human islets treated with both glucose or exendin-4, through engagement of a $\mathrm{G} \alpha$ stimulatory protein $\left(\mathrm{G} \alpha_{\mathrm{s}}\right)$ and elevation of cAMP levels (111). The insulinotropic effect of QRFP43 was suppressed when QRFPR was knocked down in INS-1E $\beta$-cells using small interfering RNA, whereas the insulinostatic effect of QRFP26a was maintained. Furthermore, QRFP43, but not QRFP26 increased glucose uptake by $\beta$-cells. At variance with the opposed effects observed on $\beta$-cell function, both peptides reduced apoptosis and cell death induced by serum starvation, inflammatory cytokines and glucolipotoxicity in $\beta$-cells and human islets, to an extent comparable to that induced by exendin-4. QRFP43-induced protection involved activation of the survival and proliferative pathways phosphatidylinositol 3-kinase/Akt and extracellular signal-related kinase 1/2 (ERK1/2), whereas only ERK1/2 was required for the survival function of QRFP26 (111). At present it is unclear why both QRFP26 and QRFP43 promote survival of $\beta$-cells, while having opposed effects on insulin secretion. The possible explanation would be that, in addition to QRFPR, these peptides bind to one or more yet unknown alternative receptors involved in their survival action.

The role of QRFP26 was recently investigated on the regulation of glucose homeostasis (107). It was demonstrated a positive association between the levels of plasma QRFP26 and plasma insulin in patients with diabetes; furthermore, QRFP26 increased in response to an oral glucose tolerance test. In mice, QRFP26 attenuated glucose-induced hyperglycemia, increased insulin sensitivity and plasma insulin concentrations but did not alter basal glycemia, suggesting antihyperglycemic action. In addition, QRFP26 promoted insulin secretion in MIN6 


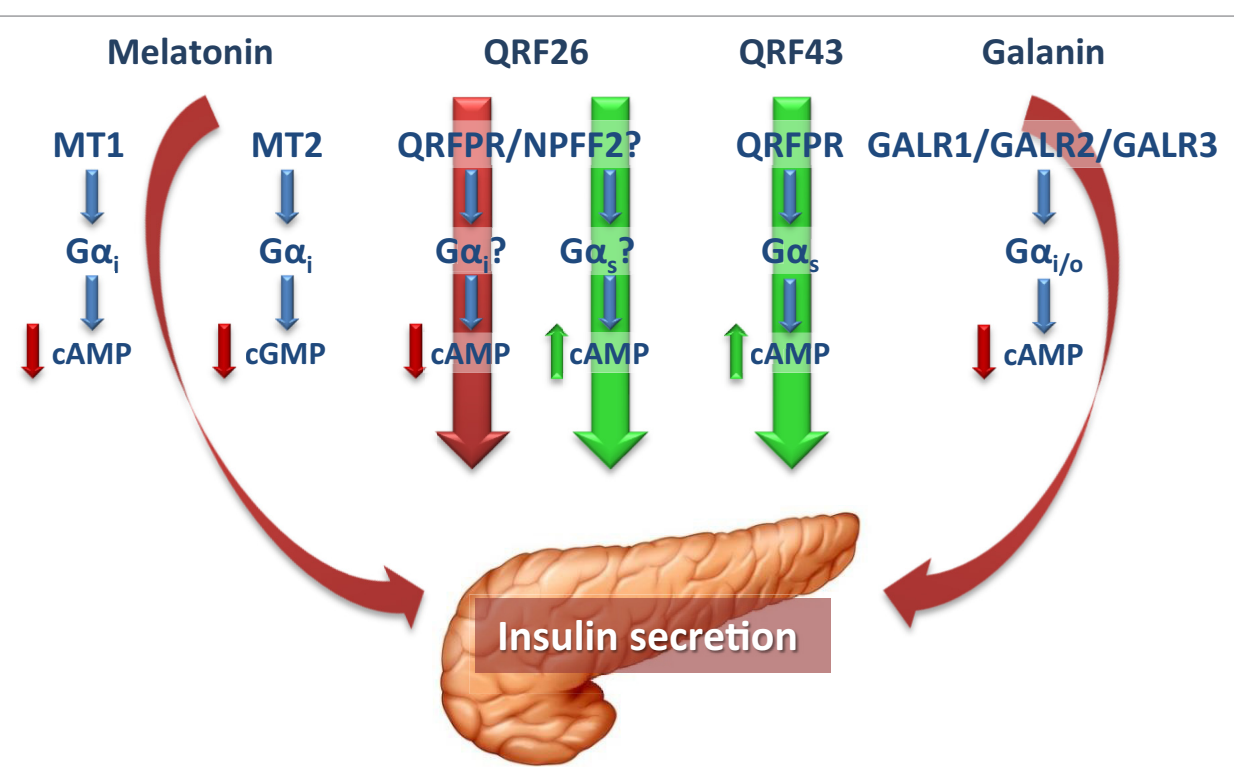

FIGURE 1 | In pancreatic $\beta$-cells, the pineal hormone melatonin reduces insulin secretion through binding to the receptor isoforms MT1 and MT2, which, by coupling to $G \alpha_{i}$ proteins, inhibit cAMP and cGMP, respectively. The hypothalamic peptide QRFP26 has been shown to both inhibit and promote insulin secretion in different $\beta$-cell models, through receptors that in part remain to be defined. The stimulatory and inhibitory actions of QRFP26 are likely mediated by activation of G $\alpha_{\text {s }}$ and $\mathrm{G} \alpha_{i}$ proteins, respectively. On the other hand, QRFP43 acts as an insulinotropic neuropeptide by binding to a G $\alpha_{s}$-coupled QRFPR, to increase cAMP levels. Galanin, widely distributed in both central and peripheral nervous systems, displays inhibitory effects in the endocrine pancreas and, like melatonin, reduces insulin secretion in $\beta$-cells by binding to $G \alpha_{i}$-coupled receptors (GALR1-3). Red and green arrows indicate the inhibitory and stimulatory effects on insulin secretion, respectively. cAMP, cyclic adenosine monophosphate; cGMP, cyclic guanosine monophosphate; GALR, galanin receptor; G $\alpha_{i}$, inhibitory guanine triphosphatebinding protein $\alpha$-subunit; $\mathrm{G} \alpha_{\mathrm{s}}$, stimulatory guanine triphosphate-binding protein $\alpha$-subunit; MT1 and MT2, melatonin receptor 1 and 2; NPFF2, neuropeptide FF receptor 2; QRFPR, QRFP receptor.

insulinoma cells, in a QRFPR-dependent manner, as inhibition of QRFPR expression using specific siRNA blocked the insulinotropic effect of the peptide. Accordingly, MIN6 showed expression for QRFPR but not for NPFF2, the other RFamide receptor that can be recognized by QRFP26. Conversely, in INS-1E $\beta$-cells the insulinostatic action of QRFP26 was independent QRFPR binding, suggesting that other receptor(s), such as NPFF2 would be involved. However, to date, the presence of NPFF2 in INS- $1 \beta$-cells or human pancreatic islets remains to be determined. Thus, the different effect of QRFP26 on insulin secretion in different $\beta$-cell types may be attributed to the different expression pattern of the receptor(s). Interestingly, in both in vivo and in vitro experiments, high concentrations of glucose induced a massive secretion of QRFP26 by the small intestine (107). Overall, at variance with the results of Granata et al. these findings indicated that QRFP26 acts as an incretin hormone to regulate glucose homeostasis.

Overall, the results from different reports indicate that QRFP26/QRFP43 regulate glucose homeostasis and $\beta$-cell function; however, further understanding is required to disentangle the discrepancies observed in the various experimental models and for elucidating the role of the receptor(s) involved in these effects. Of note, these neuropeptides increase the survival of $\beta$-cells and human pancreatic islet cells, suggesting potential therapeutic implications in diabetes.

\section{CONCLUSION}

Many important questions on the regulation of $\beta$-cell function remain unanswered, as a variety of players, and even more to be discovered, are implicated in this complex process. In addition to their central actions, it is becoming increasingly clear that, together with peripheral hormones, neuropeptides are also key regulators of glucose homeostasis and insulin secretion, displaying both direct and indirect actions in the endocrine pancreas (Figure 1). Thus, it is important to further understand their specific role and mechanisms, in order to increase the wide range of potential therapeutic targets for the treatment of diabetes and metabolic diseases.

\section{AUTHOR CONTRIBUTIONS}

IG, TV, DB, and GG contributed to the writing of the different topics and edited the manuscript; RG wrote the paper and supervised the work of the co-authors.

\section{FUNDING}

This work was supported by grants from Fondazione CRT $(2015 / 273)$ and from the University of Turin (Ex-60\% 2014 and 2015) to RG. 


\section{REFERENCES}

1. Vetere A, Choudhary A, Burns SM, Wagner BK. Targeting the pancreatic beta-cell to treat diabetes. Nat Rev Drug Discov (2014) 13:278-89. doi:10.1038/ nrd4231

2. Benthuysen JR, Carrano AC, Sander M. Advances in beta cell replacement and regeneration strategies for treating diabetes. JClin Invest (2016) 126: 3651-60. doi:10.1172/JCI87439

3. Chandra R, Liddle RA. Recent advances in the regulation of pancreatic secretion. Curr Opin Gastroenterol (2014) 30:490-4. doi:10.1097/ MOG.0000000000000099

4. Hussain MA, Akalestou E, Song WJ. Inter-organ communication and regulation of beta cell function. Diabetologia (2016) 59:659-67. doi:10.1007/ s00125-015-3862-7

5. Peschke E, Bahr I, Muhlbauer E. Experimental and clinical aspects of melatonin and clock genes in diabetes. J Pineal Res (2015) 59:1-23. doi:10.1111/ jpi. 12240

6. Acuna-Castroviejo D, Escames G, Venegas C, Diaz-Casado ME, Lima-Cabello E, Lopez LC, et al. Extrapineal melatonin: sources, regulation, and potential functions. Cell Mol Life Sci (2014) 71:2997-3025. doi:10.1007/ s00018-014-1579-2

7. Favero G, Franceschetti L, Buffoli B, Moghadasian MH, Reiter RJ, Rodella LF, et al. Melatonin: protection against age-related cardiac pathology. Ageing Res $\operatorname{Rev}$ (2016) 35:336-49. doi:10.1016/j.arr.2016.11.007

8. Forrestel AC, Miedlich SU, Yurcheshen M, Wittlin SD, Sellix MT. Chronomedicine and type 2 diabetes: shining some light on melatonin. Diabetologia (2016) 60(5):808-22. doi:10.1007/s00125-016-4175-1

9. von Gall C, Stehle JH, Weaver DR. Mammalian melatonin receptors: molecular biology and signal transduction. Cell Tissue Res (2002) 309:151-62. doi:10.1007/s00441-002-0581-4

10. Mulder H, Nagorny CL, Lyssenko V, Groop L. Melatonin receptors in pancreatic islets: good morning to a novel type 2 diabetes gene. Diabetologia (2009) 52:1240-9. doi:10.1007/s00125-009-1359-y

11. Acuna-Castroviejo D, Reiter RJ, Menendez-Pelaez A, Pablos MI, Burgos A. Characterization of high-affinity melatonin binding sites in purified cell nuclei of rat liver. J Pineal Res (1994) 16:100-12. doi:10.1111/j.1600-079X. 1994.tb00089.x

12. Becker-Andre M, Wiesenberg I, Schaeren-Wiemers N, Andre E, Missbach M, Saurat JH, et al. Pineal gland hormone melatonin binds and activates an orphan of the nuclear receptor superfamily. J Biol Chem (1994) 269:28531-4.

13. Wiesenberg I, Missbach M, Carlberg C. The potential role of the transcription factor RZR/ROR as a mediator of nuclear melatonin signaling. Restor Neurol Neurosci (1998) 12:143-50.

14. Benitez-King G, Huerto-Delgadillo L, Anton-Tay F. Binding of $3 \mathrm{H}$-melatonin to calmodulin. Life Sci (1993) 53:201-7. doi:10.1016/0024-3205(93)90670-X

15. Macias M, Escames G, Leon J, Coto A, Sbihi Y, Osuna A, et al. Calreticulinmelatonin. An unexpected relationship. Eur J Biochem (2003) 270:832-40. doi:10.1046/j.1432-1033.2003.03430.x

16. Bouatia-Naji N, Bonnefond A, Cavalcanti-Proenca C, Sparso T, Holmkvist J, Marchand $\mathrm{M}$, et al. A variant near MTNR1B is associated with increased fasting plasma glucose levels and type 2 diabetes risk. Nat Genet (2009) 41:89-94. doi:10.1038/ng.277

17. Lyssenko V, Nagorny CL, Erdos MR, Wierup N, Jonsson A, Spegel P, et al. Common variant in MTNR1B associated with increased risk of type 2 diabetes and impaired early insulin secretion. Nat Genet (2009) 41:82-8. doi:10.1038/ng.288

18. Prokopenko I, Langenberg C, Florez JC, Saxena R, Soranzo N, Thorleifsson G, et al. Variants in MTNR1B influence fasting glucose levels. Nat Genet (2009) 41:77-81. doi:10.1038/ng.290

19. Peschke E, Bahr I, Muhlbauer E. Melatonin and pancreatic islets: interrelationships between melatonin, insulin and glucagon. Int J Mol Sci (2013) 14:6981-7015. doi:10.3390/ijms14046981

20. Peschke E, Peschke D, Hammer T, Csernus V. Influence of melatonin and serotonin on glucose-stimulated insulin release from perifused rat pancreatic islets in vitro. J Pineal Res (1997) 23:156-63. doi:10.1111/j.1600-079X.1997. tb00349.x

21. Picinato MC, Haber EP, Cipolla-Neto J, Curi R, De Oliveira Carvalho CR, Carpinelli AR. Melatonin inhibits insulin secretion and decreases PKA levels without interfering with glucose metabolism in rat pancreatic islets. J Pineal Res (2002) 33:156-60. doi:10.1034/j.1600-079X.2002.02903.x

22. Tuomi T, Nagorny CL, Singh P, Bennet H, Yu Q, Alenkvist I, et al. Increased melatonin signaling is a risk factor for type 2 diabetes. Cell Metab (2016) 23:1067-77. doi:10.1016/j.cmet.2016.04.009

23. Frankel BJ, Strandberg MJ. Insulin release from isolated mouse islets in vitro: no effect of physiological levels of melatonin or arginine vasotocin. J Pineal Res (1991) 11:145-8. doi:10.1111/j.1600-079X.1991.tb00470.x

24. Kemp DM, Ubeda M, Habener JF. Identification and functional characterization of melatonin Mel la receptors in pancreatic beta cells: potential role in incretin-mediated cell function by sensitization of cAMP signaling. Mol Cell Endocrinol (2002) 191:157-66. doi:10.1016/S0303-7207(02)00064-3

25. Peschke E, Bach AG, Muhlbauer E. Parallel signaling pathways of melatonin in the pancreatic beta-cell. J Pineal Res (2006) 40:184-91. doi:10.1111/ j.1600-079X.2005.00297.x

26. Muhlbauer E, Albrecht E, Bazwinsky-Wutschke I, Peschke E. Melatonin influences insulin secretion primarily via MT(1) receptors in rat insulinoma cells (INS-1) and mouse pancreatic islets. J Pineal Res (2012) 52:446-59. doi:10.1111/j.1600-079X.2012.00959.x

27. Muhlbauer E, Peschke E. Evidence for the expression of both the MT1- and in addition, the MT2-melatonin receptor, in the rat pancreas, islet and beta-cell. J Pineal Res (2007) 42:105-6. doi:10.1111/j.1600-079X.2006.00399.x

28. Muhlbauer E, Albrecht E, Hofmann K, Bazwinsky-Wutschke I, Peschke E. Melatonin inhibits insulin secretion in rat insulinoma beta-cells (INS-1) heterologously expressing the human melatonin receptor isoform MT2. J Pineal Res (2011) 51:361-72. doi:10.1111/j.1600-079X.2011.00898.x

29. Ramracheya RD, Muller DS, Squires PE, Brereton H, Sugden D, Huang GC, et al. Function and expression of melatonin receptors on human pancreatic islets. J Pineal Res (2008) 44:273-9. doi:10.1111/j.1600-079X.2007.00523.x

30. Bahr I, Muhlbauer E, Schucht H, Peschke E. Melatonin stimulates glucagon secretion in vitro and in vivo. JPineal Res (2011) 50:336-44. doi:10.1111/j.1600-079X.2010.00848.x

31. Benson B, Miller CW, Sorrentino S Jr. Effects of blinding on blood glucose and serum insulin-like activity in rats. Tex Rep Biol Med (1971) 29: 513-25.

32. Burns JK. Serum sodium and potassium and blood glucose levels in cynamolgus monkeys after administration of melatonin. J Physiol (1973) 232:84P-5.

33. Gorray KC, Quay WB. Effects of pinealectomy and of sham-pinealectomy on blood glucose levels in the alloxan-diabetic rat. Horm Metab Res (1978) 10:389-92. doi:10.1055/s-0028-1093398

34. Quay WB, Gorray KC. Pineal effects on metabolism and glucose homeostasis: evidence for lines of humoral mediation of pineal influences on tumor growth. J Neural Transm (1980) 47:107-20. doi:10.1007/BF01670162

35. Dhar M, Dayal SS, Ramesh Babu CS, Arora SR. Effect of melatonin on glucose tolerance and blood glucose circadian rhythm in rabbits. Indian J Physiol Pharmacol (1983) 27:109-17.

36. Rasmussen DD, Boldt BM, Wilkinson CW, Yellon SM, Matsumoto AM. Daily melatonin administration at middle age suppresses male rat visceral fat, plasma leptin, and plasma insulin to youthful levels. Endocrinology (1999) 140:1009-12. doi:10.1210/endo.140.2.6674

37. Cagnacci A, Arangino S, Renzi A, Paoletti AM, Melis GB, Cagnacci P, et al. Influence of melatonin administration on glucose tolerance and insulin sensitivity of postmenopausal women. Clin Endocrinol (Oxf) (2001) 54:339-46. doi:10.1046/j.1365-2265.2001.01232.x

38. Rasmussen DD, Mitton DR, Larsen SA, Yellon SM. Aging-dependent changes in the effect of daily melatonin supplementation on rat metabolic and behavioral responses. J Pineal Res (2001) 31:89-94. doi:10.1034/j. 1600-079X.2001.310113.x

39. Champney TH, Steger RW, Christie DS, Reiter RJ. Alterations in components of the pineal melatonin synthetic pathway by acute insulin stress in the rat and Syrian hamster. Brain Res (1985) 338:25-32. doi:10.1016/ 0006-8993(85)90244-6

40. Boden G, Ruiz J, Urbain JL, Chen X. Evidence for a circadian rhythm of insulin secretion. Am J Physiol (1996) 271:E246-52.

41. Ibanez-Costa A, Cordoba-Chacon J, Gahete MD, Kineman RD, Castano JP, Luque RM. Melatonin regulates somatotrope and lactotrope function through common and distinct signaling pathways in cultured primary pituitary cells from female primates. Endocrinology (2015) 156:1100-10. doi:10.1210/ en.2014-1819 
42. Terzolo M, Revelli A, Guidetti D, Piovesan A, Cassoni P, Paccotti P, et al. Evening administration of melatonin enhances the pulsatile secretion of prolactin but not of LH and TSH in normally cycling women. Clin Endocrinol (Oxf) (1993) 39:185-91. doi:10.1111/j.1365-2265.1993.tb01772.x

43. Kostoglou-Athanassiou I, Treacher DF, Wheeler MJ, Forsling ML. Melatonin administration and pituitary hormone secretion. Clin Endocrinol (Oxf) (1998) 48:31-7. doi:10.1046/j.1365-2265.1998.00341.x

44. Forsling ML, Wheeler MJ, Williams AJ. The effect of melatonin administration on pituitary hormone secretion in man. Clin Endocrinol (Oxf) (1999) 51:637-42. doi:10.1046/j.1365-2265.1999.00820.x

45. Tsukamoto N, Otsuka F, Ogura-Ochi K, Inagaki K, Nakamura E, Toma K, et al. Melatonin receptor activation suppresses adrenocorticotropin production via BMP-4 action by pituitary AtT20 cells. Mol Cell Endocrinol (2013) 375:1-9. doi:10.1016/j.mce.2013.05.010

46. Tatemoto K, Rokaeus A, Jornvall H, Mcdonald TJ, Mutt V. Galanin a novel biologically active peptide from porcine intestine. FEBS Lett (1983) 164:124-8. doi:10.1016/0014-5793(83)80033-7

47. Cheung A, Polak JM, Bauer FE, Cadieux A, Christofides ND, Springall DR, et al. Distribution of galanin immunoreactivity in the respiratory tract of pig, guinea pig, rat, and dog. Thorax (1985) 40:889-96. doi:10.1136/thx.40. 12.889

48. Skofitsch G, Jacobowitz DM. Immunohistochemical mapping of galaninlike neurons in the rat central nervous system. Peptides (1985) 6:509-46. doi:10.1016/0196-9781(85)90118-4

49. Dunning BE, Ahren B, Veith RC, Bottcher G, Sundler F, Taborsky GJ Jr. Galanin: a novel pancreatic neuropeptide. Am J Physiol (1986) 251:E127-33.

50. Podlasz P, Sallinen V, Chen YC, Kudo H, Fedorowska N, Panula P. Galanin gene expression and effects of its knock-down on the development of the nervous system in larval zebrafish. J Comp Neurol (2012) 520:3846-62. doi:10.1002/cne.23131

51. Lang R, Gundlach AL, Holmes FE, Hobson SA, Wynick D, Hokfelt T, et al. Physiology, signaling, and pharmacology of galanin peptides and receptors: three decades of emerging diversity. Pharmacol Rev (2015) 67:118-75. doi:10.1124/pr.112.006536

52. Melander T, Hokfelt T, Rokaeus A. Distribution of galaninlike immunoreactivity in the rat central nervous system. J Comp Neurol (1986) 248:475-517. doi:10.1002/cne.902480404

53. Zini S, Roisin MP, Langel U, Bartfai T, Ben-Ari Y. Galanin reduces release of endogenous excitatory amino acids in the rat hippocampus. Eur J Pharmacol (1993) 245:1-7. doi:10.1016/0922-4106(93)90162-3

54. Misane I, Razani H, Wang FH, Jansson A, Fuxe K, Ogren SO. Intraventricular galanin modulates a 5-HT1A receptor-mediated behavioural response in the rat. Eur J Neurosci (1998) 10:1230-40. doi:10.1046/j.1460-9568.1998. 00132.x

55. Mazarati AM, Hohmann JG, Bacon A, Liu H, Sankar R, Steiner RA, et al. Modulation of hippocampal excitability and seizures by galanin. J Neurosci (2000) 20:6276-81.

56. Crawley JN. Galanin impairs cognitive abilities in rodents: relevance to Alzheimer's disease. Cell Mol Life Sci (2008) 65:1836-41. doi:10.1007/ s00018-008-8158-3

57. Hobson SA, Bacon A, Elliot-Hunt CR, Holmes FE, Kerr NC, Pope R, et al. Galanin acts as a trophic factor to the central and peripheral nervous systems. Cell Mol Life Sci (2008) 65:1806-12. doi:10.1007/s00018-008-8154-7

58. Lerner JT, Sankar R, Mazarati AM. Galanin and epilepsy. Cell Mol Life Sci (2008) 65:1864-71. doi:10.1007/s00018-008-8161-8

59. Branchek TA, Smith KE, Gerald C, Walker MW. Galanin receptor subtypes. Trends Pharmacol Sci (2000) 21:109-17. doi:10.1016/S0165-6147(00)01446-2

60. Lindskog S, Ahren B, Dunning BE, Sundler F. Galanin-immunoreactive nerves in the mouse and rat pancreas. Cell Tissue Res (1991) 264:363-8. doi:10.1007/BF00313975

61. Adeghate E, Ponery AS. Large reduction in the number of galaninimmunoreactive cells in pancreatic islets of diabetic rats. J Neuroendocrinol (2001) 13:706-10. doi:10.1046/j.1365-2826.2001.00682.x

62. Ahren B, Ar'rajab A, Bottcher G, Sundler F, Dunning BE. Presence of galanin in human pancreatic nerves and inhibition of insulin secretion from isolated human islets. Cell Tissue Res (1991) 264:263-7. doi:10.1007/BF00313963

63. McDonald TJ, Brooks BD, Rokaeus A, Tinner B, Staines WA. Pancreatic galanin: molecular forms and anatomical locations. Pancreas (1992) 7:624-35. doi:10.1097/00006676-199211000-00002
64. Shimosegawa T, Moriizumi S, Koizumi M, Kashimura J, Yanaihara N, Toyota T. Immunohistochemical demonstration of galaninlike immunoreactive nerves in the human pancreas. Gastroenterology (1992) 102:263-71. doi:10.1016/0016-5085(92)91809-I

65. McDonald TJ, Dupre J, Tatemoto K, Greenberg GR, Radziuk J, Mutt V. Galanin inhibits insulin secretion and induces hyperglycemia in dogs. Diabetes (1985) 34:192-6. doi:10.2337/diabetes.34.2.192

66. Lindskog S, Dunning BE, Martensson H, Ar'rajab A, Taborsky GJ Jr, Ahren B. Galanin of the homologous species inhibits insulin secretion in the rat and in the pig. Acta Physiol Scand (1990) 139:591-6. doi:10.1111/j.1748-1716.1990. tb08963.x

67. Manabe T, Okada Y, Sawai H, Funahashi H, Yamamoto M, Hayakawa T, et al. Effect of galanin on plasma glucose, insulin and pancreatic glucagon in dogs. J Int Med Res (2003) 31:126-32. doi:10.1177/147323000303100209

68. Abdul-Rahman O, Sasvari-Szekely M, Ver A, Rosta K, Szasz BK, Kereszturi E, et al. Altered gene expression profiles in the hippocampus and prefrontal cortex of type 2 diabetic rats. BMC Genomics (2012) 13:81. doi:10.1186/1471-2164-13-81

69. Dunning BE, Taborsky GJ Jr. Galanin release during pancreatic nerve stimulation is sufficient to influence islet function. Am J Physiol (1989) 256: E191-8.

70. Bauer FE, Zintel A, Kenny MJ, Calder D, Ghatei MA, Bloom SR. Inhibitory effect of galanin on postprandial gastrointestinal motility and gut hormone release in humans. Gastroenterology (1989) 97:260-4. doi:10.1016/ 0016-5085(89)90059-0

71. Gilbey SG, Stephenson J, O’Halloran DJ, Burrin JM, Bloom SR. High-dose porcine galanin infusion and effect on intravenous glucose tolerance in humans. Diabetes (1989) 38:1114-6. doi:10.2337/diab.38.9.1114

72. Ahren B. Effects of galanin and calcitonin gene-related peptide on insulin and glucagon secretion in man. Acta Endocrinol (Copenh) (1990) 123:591-7.

73. Milewicz A, Mikulski E, Bidzinska B. Plasma insulin, cholecystokinin, galanin, neuropeptide $\mathrm{Y}$ and leptin levels in obese women with and without type 2 diabetes mellitus. Int J Obes Relat Metab Disord (2000) 24(Suppl 2):S152-3. doi:10.1038/sj.ijo.0801310

74. Gregersen S, Hermansen K, Langel U, Fisone G, Bartfai T, Ahren B. Galanininduced inhibition of insulin secretion from rat islets: effects of rat and pig galanin and galanin fragments and analogues. Eur J Pharmacol (1991) 203:111-4. doi:10.1016/0014-2999(91)90797-T

75. Olkowicz M, Ruczynski J, Cybal M, Konstanski Z, Petrusewicz J, Kaminska B, et al. New galanin(1-15) analogues modified in positions 9, 10 and 11 act as galanin antagonists on glucose-induced insulin secretion. J Physiol Pharmacol (2007) 58:859-72.

76. Ruczynski J, Konstanski Z, Cybal M, Kocic I, Rekowski P. Aspartimide modified galanin analogue antagonizes galanin action on insulin secretion. Protein Pept Lett (2010) 17:1182-8. doi:10.2174/092986610792231447

77. Tang G, Wang Y, Park S, Bajpayee NS, Vi D, Nagaoka Y, et al. Go2 G protein mediates galanin inhibitory effects on insulin release from pancreatic beta cells. Proc Natl Acad Sci U S A (2012) 109:2636-41. doi:10.1073/pnas. 1200100109

78. McDonald TJ, Tu E, Brenner S, Zabel P, Behme M, Panchal C, et al. Canine, human, and rat plasma insulin responses to galanin administration: species response differences. Am J Physiol (1994) 266:E612-7.

79. Poritsanos NJ, Mizuno TM, Lautatzis ME, Vrontakis M. Chronic increase of circulating galanin levels induces obesity and marked alterations in lipid metabolism similar to metabolic syndrome. Int J Obes (Lond) (2009) 33:1381-9. doi:10.1038/ijo.2009.187

80. Ahren B, Pacini G, Wynick D, Wierup N, Sundler F. Loss-of-function mutation of the galanin gene is associated with perturbed islet function in mice. Endocrinology (2004) 145:3190-6. doi:10.1210/en.2003-1700

81. Holst JJ, Bersani M, Hvidberg A, Knigge U, Christiansen E, Madsbad S, et al. On the effects of human galanin in man. Diabetologia (1993) 36:653-7. doi:10.1007/BF00404076

82. Mazziotti G, Bonadonna S, Doga M, Patelli I, Gazzaruso C, Solerte SB, et al. Biochemical evaluation of patients with active acromegaly and type 2 diabetes mellitus: efficacy and safety of the galanin test. Neuroendocrinology (2008) 88:299-304. doi:10.1159/000144046

83. Dunning BE, Ahren B. Reduced pancreatic content of the inhibitory neurotransmitter galanin in genetically obese, hyperinsulinemic mice. Pancreas (1992) 7:233-9. doi:10.1097/00006676-199203000-00016 
84. Baltazar ET, Kitamura N, Hondo E, Narreto EC, Yamada J. Galanin-like immunoreactive endocrine cells in bovine pancreas. J Anat (2000) 196 (Pt 2):285-91. doi:10.1046/j.1469-7580.2000.19620285.x

85. Flynn SP, White HS. Regulation of glucose and insulin release following acute and repeated treatment with the synthetic galanin analog NAX-5055. Neuropeptides (2015) 50:35-42. doi:10.1016/j.npep.2015.01.001

86. Fang P, Min W, Sun Y, Guo L, Shi M, Bo P, et al. The potential antidepressant and antidiabetic effects of galanin system. Pharmacol Biochem Behav (2014) 120:82-7. doi:10.1016/j.pbb.2014.02.018

87. Kageyama H, Shiba K, Hirako S, Wada N, Yamanaka S, Nogi Y, et al. Antiobesity effect of intranasal administration of galanin-like peptide (GALP) in obese mice. Sci Rep (2016) 6:28200. doi:10.1038/srep28200

88. Fraley GS, Shimada I, Baumgartner JW, Clifton DK, Steiner RA. Differential patterns of Fos induction in the hypothalamus of the rat following central injections of galanin-like peptide and galanin. Endocrinology (2003) 144:1143-6. doi:10.1210/en.2002-0114

89. Krasnow SM, Fraley GS, Schuh SM, Baumgartner JW, Clifton DK, Steiner RA. A role for galanin-like peptide in the integration of feeding, body weight regulation, and reproduction in the mouse. Endocrinology (2003) 144:813-22. doi:10.1210/en.2002-220982

90. Chartrel N, Dujardin C, Anouar Y, Leprince J, Decker A, Clerens S, et al. Identification of 26RFa, a hypothalamic neuropeptide of the RFamide peptide family with orexigenic activity. Proc Natl Acad Sci US A (2003) 100: 15247-52. doi:10.1073/pnas.2434676100

91. Fukusumi S, Yoshida H, Fujii R, Maruyama M, Komatsu H, Habata Y, et al. A new peptidic ligand and its receptor regulating adrenal function in rats. J Biol Chem (2003) 278:46387-95. doi:10.1074/jbc.M305270200

92. Jiang Y, Luo L, Gustafson EL, Yadav D, Laverty M, Murgolo N, et al. Identification and characterization of a novel RF-amide peptide ligand for orphan G-protein-coupled receptor SP9155. J Biol Chem (2003) 278:27652-7. doi:10.1074/jbc.M302945200

93. Liu Y, Zhang Y, Li S, Huang W, Liu X, Lu D, et al. Molecular cloning and functional characterization of the first non-mammalian 26RFa/QRFP orthologue in Goldfish, Carassius auratus. Mol Cell Endocrinol (2009) 303:82-90. doi:10.1016/j.mce.2009.01.009

94. Ukena K, Tachibana T, Iwakoshi-Ukena E, Saito Y, Minakata H, Kawaguchi R, et al. Identification, localization, and function of a novel avian hypothalamic neuropeptide, 26RFa, and its cognate receptor, G proteincoupled receptor-103. Endocrinology (2010) 151:2255-64. doi:10.1210/ en.2009-1478

95. Sandvik GK, Hodne K, Haug TM, Okubo K, Weltzien FA. RFamide peptides in early vertebrate development. Front Endocrinol (2014) 5:203. doi:10.3389/ fendo.2014.00203

96. Ukena K, Osugi T, Leprince J, Vaudry H, Tsutsui K. Molecular evolution of GPCRs: 26Rfa/GPR103. J Mol Endocrinol (2014) 52:T119-31. doi:10.1530/ JME-13-0207

97. Chartrel N, Picot M, El Medhi M, Arabo A, Berrahmoune H, Alexandre D, et al. The neuropeptide 26RFa (QRFP) and its role in the regulation of energy homeostasis: a mini-review. Front Neurosci (2016) 10:549. doi:10.3389/fnins. 2016.00549

98. Dockray GJ. The expanding family of -RFamide peptides and their effects on feeding behaviour. Exp Physiol (2004) 89:229-35. doi:10.1113/expphysiol. 2004.027169

99. Kampe J, Wiedmer P, Pfluger PT, Castaneda TR, Burget L, Mondala H, et al. Effect of central administration of QRFP(26) peptide on energy balance and characterization of a second QRFP receptor in rat. Brain Res (2006) 1119:133-49. doi:10.1016/j.brainres.2006.08.055

100. Takayasu S, Sakurai T, Iwasaki S, Teranishi H, Yamanaka A, Williams SC, et al. A neuropeptide ligand of the G protein-coupled receptor GPR103 regulates feeding, behavioral arousal, and blood pressure in mice. Proc Natl Acad Sci U S A (2006) 103:7438-43. doi:10.1073/pnas.0602371103

101. Bruzzone F, Lectez B, Alexandre D, Jegou S, Mounien L, Tollemer H, et al. Distribution of 26RFa binding sites and GPR103 mRNA in the central nervous system of the rat. J Comp Neurol (2007) 503:573-91. doi:10.1002/ cne. 21400

102. do Rego JC, Leprince J, Chartrel N, Vaudry H, Costentin J. Behavioral effects of 26RFamide and related peptides. Peptides (2006) 27:2715-21. doi:10.1016/j.peptides.2006.04.017

103. Moriya R, Sano H, Umeda T, Ito M, Takahashi Y, Matsuda M, et al. RFamide peptide QRFP43 causes obesity with hyperphagia and reduced thermogenesis in mice. Endocrinology (2006) 147:2916-22. doi:10.1210/en.2005-1580

104. Jossart C, Mulumba M, Granata R, Gallo D, Ghigo E, Marleau S, et al. Pyroglutamylated RF-amide peptide (QRFP) gene is regulated by metabolic endotoxemia. Mol Endocrinol (2010) 28:65-79. doi:10.1210/me.2013-1027

105. Mulumba M, Jossart C, Granata R, Gallo D, Escher E, Ghigo E, et al. GPR103b functions in the peripheral regulation of adipogenesis. Mol Endocrinol (2010) 24:1615-25. doi:10.1210/me.2010-0010

106. Mulumba M, Granata R, Marleau S, Ong H. QRFP-43 inhibits lipolysis by preventing ligand-induced complex formation between perilipin $\mathrm{A}$, caveolin-1, the catalytic subunit of protein kinase and hormone-sensitive lipase in 3T3-L1 adipocytes. Biochim Biophys Acta (2015) 1851:657-66. doi:10.1016/j.bbalip.2015.02.005

107. Prevost G, Jeandel L, Arabo A, Coeffier M, El Ouahli M, Picot M, et al. Hypothalamic neuropeptide $26 \mathrm{RFa}$ acts as ancretin to regulate glucose homeostasis. Diabetes (2015) 64:2805-16. doi:10.2337/db14-1864

108. Baribault H, Danao J, Gupte J, Yang L, Sun B, Richards W, et al. The G-protein-coupled receptor GPR103 regulates bone formation. Mol Cell Biol (2006) 26:709-17. doi:10.1128/MCB.26.2.709-717.2006

109. Navarro VM, Fernandez-Fernandez R, Nogueiras R, Vigo E, Tovar S, Chartrel N, et al. Novel role of 26RFa, a hypothalamic RFamide orexigenic peptide, as putative regulator of the gonadotropic axis. J Physiol (2006) 573:237-49. doi:10.1113/jphysiol.2006.106856

110. Patel SR, Murphy KG, Thompson EL, Patterson M, Curtis AE, Ghatei MA, et al. Pyroglutamylated RFamide peptide 43 stimulates the hypothalamicpituitary-gonadal axis via gonadotropin-releasing hormone in rats. Endocrinology (2008) 149:4747-54. doi:10.1210/en.2007-1562

111. Granata R, Settanni F, Trovato L, Gallo D, Gesmundo I, Nano R, et al. RFamide peptides $43 \mathrm{RFa}$ and $26 \mathrm{RFa}$ both promote survival of pancreatic beta-cells and human pancreatic islets but exert opposite effects on insulin secretion. Diabetes (2014) 63:2380-93. doi:10.2337/db13-1522

112. Lee DK, Nguyen T, Lynch KR, Cheng R, Vanti WB, Arkhitko O, et al. Discovery and mapping of ten novel $G$ protein-coupled receptor genes. Gene (2001) 275:83-91. doi:10.1016/S0378-1119(01)00651-5

113. Egido EM, Hernandez R, Leprince J, Chartrel N, Vaudry H, Marco J, et al. 26RFa, a novel orexigenic neuropeptide, inhibits insulin secretion in the rat pancreas. Peptides (2007) 28:725-30. doi:10.1016/j.peptides.2006. 04.004

Conflict of Interest Statement: The authors declare that the research was conducted in the absence of any commercial or financial relationships that could be construed as a potential conflict of interest.

Copyright (c) 2017 Gesmundo, Villanova, Banfi, Gamba and Granata. This is an open-access article distributed under the terms of the Creative Commons Attribution License (CC BY). The use, distribution or reproduction in other forums is permitted, provided the original author(s) or licensor are credited and that the original publication in this journal is cited, in accordance with accepted academic practice. No use, distribution or reproduction is permitted which does not comply with these terms. 